\title{
The Risk Factors of Motorcycle Riders Traffic Accidents in Semarang City 2017
}

\author{
Mochammad Malik Ibrahim, ${ }^{1}$ Mateus Sakundarno Adi, ${ }^{2}$ Suhartono ${ }^{3}$ \\ ${ }^{1}$ STIKES Arrahmah Mandiri Indonesia, Pasuruan, Indonesia, ${ }^{2}$ Master in Epidemiology Study Program, \\ Postgraduate School, Universitas Diponegoro, Semarang, Indonesia, ${ }^{3}$ Master in Environmental Health \\ Study Program, Faculty of Public Health, Universitas Diponegoro, Semarang, Indonesia
}

\begin{abstract}
The incidence rate of motorcycle accidents in Semarang city increased every year in the period 2014-2016. The research related to the risk factor of traffic accident incidents on motorcycle riders in Semarang city is still scarce. This study aims to analyze the risk factors of traffic accidents on motorcycle riders in Semarang city. The type of research is an analytic observational study with a case-control design. The number of samples was 50 cases and 50 controls. The case is a motorcycle rider who had a traffic accident in Semarang city from July to November 2017. Control is a motorcycle rider who did not have a traffic accident. Data was analyzed bivariate and multivariate using logistic regression test backward LR method. Factors proven to be a risk factor for traffic accidents on motorcyclists are less alert $(\mathrm{p}=0.005, \mathrm{OR}=4.255,95 \% \mathrm{CI}=1.540-11.759)$, non-distance habits $(\mathrm{p}=0.001, \mathrm{OR}=5.209$, 95\% CI=1.997-13.584), and hasty behavior ( $\mathrm{p}=0.029, \mathrm{OR}=2.950,95 \% \mathrm{CI}=1.116-7.800)$. Conclusions, alertness, not keeping distance, and impulsive behavior are risk factors for traffic accident incidents on Semarang city motorcyclists.
\end{abstract}

Keywords: Motorcycle, risk factors, traffic accidents

\section{Faktor Risiko Kecelakaan Lalu Lintas Pengendara Sepeda Motor di Kota Semarang Tahun 2017}

\begin{abstract}
Abstrak
Angka insidensi kecelakaan sepeda motor di Kota Semarang meningkat setiap tahun dalam kurun waktu 20142016. Penelitian terkait faktor risiko kejadian kecelakaan lalu lintas pada pengendara sepeda motor di Kota Semarang masih sangat jarang dilakukan. Penelitian ini bertujuan menganalisis faktor risiko kejadian kecelakaan lalu lintas pada pengendara sepeda motor di Kota Semarang. Jenis penelitian adalah studi observasional analitik dengan desain case control. Jumlah sampel 50 kasus dan 50 kontrol. Kasus adalah pengendara sepeda motor yang mengalami kecelakaan lalu lintas di Kota Semarang terhitung dari Juli hingga November 2017. Kontrol adalah pengendara sepeda motor yang tidak mengalami kecelakaan lalu lintas. Data dianalisis secara bivariat dan multivariat menggunakan uji logistic regression metode backward LR. Faktor yang terbukti sebagai faktor risiko kejadian kecelakaan lalu lintas pada pengendara sepeda motor adalah kurang waspada $(\mathrm{p}=0,005 ; \mathrm{OR}=4,255 ; \mathrm{IK}$ $95 \%=1,540-11,759)$, kebiasaan tidak menjaga jarak $(\mathrm{p}=0,001 ; \mathrm{OR}=5,209$; IK 95\%=1,997-13,584), dan perilaku terburu-buru ( $\mathrm{p}=0,029 ; \mathrm{OR}=2,950$; IK 95\%=1,116-7,800). Simpulan, kurang waspada, kebiasaan tidak menjaga jarak, dan perilaku terburu-buru merupakan faktor risiko kejadian kecelakaan lalu lintas pada pengendara sepeda motor di Kota Semarang.
\end{abstract}

Kata kunci: Faktor risiko, kecelakaan lalu lintas, sepeda motor

Received: 4 May 2018; Revised: 28 July 2020; Accepted: 2 December 2020; Published: 31 December 2020

Correspondence: Mochammad Malik Ibrahim, S.K.M., M.K.M. STIKES Arrahma Mandiri Indonesia. Jln. Raya Carat Gempol, Pasuruan 67155, East Java, Indonesia. E-mail: mochammad.malik.ibrahim@gmail.com 


\section{Introduction}

The World Health Organization (WHO) report in 2013 predicts that around 1.24 million people die in traffic accidents each year. Traffic accidents resulted in 33,815 deaths in the South-East Asia Region (SEAR) in 2010, with an average of 18.5 deaths per 100,000 population. ${ }^{1}$ In Indonesia, the number of traffic accidents in the year 2010 is 28 per 100,000 population. ${ }^{2,3}$ In Central Java, the incidence of traffic accidents in 2013 has a pretrial rate of 57 per 100,000 population. ${ }^{4,5}$ Incidence rate of motorcycle accidents in Semarang city based on the number of registered vehicles, i.e. 8.25 per 100,000 registered motorcycles in 2014, 8.69 years per 100,000 registered motorcycle vehicles in 2015, and 10.97 per 100,000 registered motor vehicles in 2016.6,7

Traffic risk factors for motorcycle riders include: no driver license ${ }^{8}$, rider condition: tired condition, ${ }^{9}$ sleepy condition, ${ }^{9}$ drunk condition; ${ }^{10}$ not alert; ${ }^{10,11}$ not turning on the light; $;^{12}$ driving at high speed; $; 8$ use of lane; ${ }^{13}$ violating the mark; ${ }^{14}$ violating the traffic lights; $;$ distance of vehicle too close $;^{10,16}$ hasty behavior. ${ }^{17}$

The preliminary study from 3,009 cases of motorcycle accidents in Semarang city 20142016 is as follows; less alertness (51.5\%) followed by breaking lane (28.5\%), breaking distance (9.2\%), hasty behavior (8.6\%), high speed (3.7\%), violating the mark (2.3\%), violating the traffic lights (1.5\%), tired condition (0.5\%), drowsiness (0.6\%), drunk condition (0.5\%), and improper headlight turning (0.3\%).

The incidence of motorbike accident incidents has increased over the past three years. The magnitude of losses incurred by motorcycle riders as the largest contributor to the vehicle involved in accidents has led to the importance of special assessments and handling. Secondary data of causal factors and motorcycle traffic accidents in Semarang city has been done data processing in the initial research. However, some variables are considered essential and suspected as a risk factor for traffic accidents on motorcyclists.

The research related to traffic accidents' risk factors on motorcycle riders in Semarang city is still scarce. It is necessary to do this research to analyze the risk factors of traffic accident incidents on motorcycle riders in Semarang city.

\section{Methods}

The research is an analytic observational study with a case-control design. Consecutive sampling was used to choose 50 from 527 motorcyclists who had traffic accidents. The traffic accidents report was collected from the Resort Police of Semarang city from July to November 2017. The inclusion criteria are motorists who crashed or nudged, injured or not injured, suffered a traffic accident in the Semarang city. According to the identity card, they resided in Semarang city, recorded in the accident report Semarang city police traffic, and are willing to become respondents. In comparison, the exclusion criteria are death, defect, and no complete record of the identity.

Controls are motorcyclists without traffic accidents. Inclusion criteria are being able to ride a motorcycle, driving on the road where the accident occurred on the same day as the case, driving past the accident, residing in Semarang city according to the identity card, and being willing to be a respondent. For matching case and control groups: road and time variables.

Before data collection, we described the research's aim, and subjects signed informed consent if they agree to participate. We used questionnaires that have been tested for validity. The data includes sex, age, work type, motor type, rider speed, driver license ownership, violating traffic light habits, driving usage, rider alert, impulsive behavior, and violating the line mark habits. Data analysis used the chi-square test for bivariate analysis and multivariate analysis using logistic regression test of Backward LR method.

This study was approved by the Health Research Ethics Committee of Faculty of Public Health of Universitas Diponegoro Semarang with the letter number: 105/EC/FKM/2017.

\section{Results}

Table 1 shows the characteristic of respondents. Based on Table 1, the male proportion is almost the same in the case group 35 of 50 and the control group 41 of $50 \quad(p=0.334)$. Subjects proportion aged $<18$ years was higher in the case group (9 of 50) than in the control group (o of $50, p=0.004)$. Subjects proportion who never attended school, did not finish primary school, finished from elementary school, finished from junior high school, and finished high school/ vocational school are almost the same in both case and control groups with $\mathrm{p}=0.176$. The proportion of non-working subjects was higher in the case group ( 4 of 50) than in the control group. The student proportion in the case group was 17 
Table 1 Characteristic of Respondents

\begin{tabular}{lrrr}
\hline \multirow{2}{*}{ Characteristics } & \multicolumn{2}{c}{ Groups } & \multirow{2}{*}{ p Value } \\
\cline { 2 - 3 } & Case (n=50) & Control (n=50) & \multirow{2}{*}{0.334} \\
Sex & 37 & & \\
Male & 13 & 91 & \multirow{2}{*}{0.004} \\
Female & & & \\
Age (years) & 9 & 0 & \\
$<18$ & 15 & 31 & \\
$18-25$ & 20 & 2 & \\
$26-59$ & 6 & & \\
$\geq 60$ & & 1 & \\
Education & 1 & 3 & \\
Never attended school & 0 & 3 & \\
Not finished primary school & 7 & 5 & \\
Finished elementary school & 11 & 34 & \\
Finished junior high school & 27 & 4 & \\
Finished high school & 4 & & \\
Graduated from college & & 0 & \\
Occupation & 4 & 7 & \\
$\quad$ Unemployment & 17 & 1 & \\
Student & 1 & 16 & \\
Goverment employee & 14 & 25 & \\
Private employee & 12 & 1 & \\
Entrepreneur & 2 & & \\
Farmers/Fishermen/laborers & & & \\
\hline
\end{tabular}

of 50 more than the control group (7 of 50) with $\mathrm{p}=0.02$.

Results of the bivariate analysis showed that the variable that proved to be a traffic accidents risk factor on motorcycle riders was $\geq 50 \mathrm{~km} /$ hour speed $(\mathrm{p}=0.006, \mathrm{OR}=4.49,95 \% \mathrm{CI}=1.61-$ 12.54), no driver license $(\mathrm{p}=0.035, \mathrm{OR}=3.16$, $95 \% \mathrm{CI}=1.17-8.51)$, use of a bad lane $(\mathrm{p}=0.001$, $\mathrm{OR}=4.89, \quad 95 \% \quad \mathrm{CI}=2.04-11.72)$, less alert ( $\mathrm{p}=0.000, \mathrm{OR}=6.29,95 \% \mathrm{CI}=2.52-15.69)$, hasty behavior $(\mathrm{p}=0.002, \mathrm{OR}=3.93,95 \% \mathrm{CI}=1.68-$ 9.15), habit not keeping the distance ( $\mathrm{p}=0.000$, $\mathrm{OR}=7.31,95 \% \mathrm{CI}=3.02-17.70$ ) which can be seen in Table 2.

The independent variable used as the candidate for the logistic regression test is a bivariate analysis variable (chi-square) with a $\mathrm{p}$ value $<0.25$. There are eight variables included in the multivariate analysis of impulsive behavior, rider speed, driver license ownership, use of the lane, alertness of rider, keeping the distance, violating the mark, and motor type. Results of multivariate analysis showed that the factors that proved to be a traffic accident risk factor on motorcyclists were less alert $(\mathrm{p}=0.005$, $\mathrm{OR}=4.255,95 \% \mathrm{CI}=1.540-11.759)$, non-distance habits $(\mathrm{p}=0.001, \mathrm{OR}=5.209,95 \% \mathrm{CI}=1.997-$ 13.584), and hasty behavior $(\mathrm{p}=0.029, \mathrm{OR}=2.950$, 95\% CI $=1.116-7.800$ ) which can be seen in Table 3 .

Backward results, it is known that rider alertness variable $\left(b_{1}=1.448\right)$, keep distance $\left(b_{2}=1.650\right)$, and hasty behavior $\left(b_{3}=1,082\right)$.

So the regression equation:

$$
\begin{aligned}
& y=a+b_{1} X_{1}+b_{2} X_{2}+\ldots .+b_{i} X_{i} \\
& y=-1.995+1.448 . X_{1}+1.650 . X_{2}+1.082 . X_{3} \\
& p=\frac{1}{1+e^{-\left(a+b_{1} X_{1}+b_{2} X_{2}+\ldots .+b_{i} X_{i}\right)}}
\end{aligned}
$$

The calculation results show that people who are less alert when riding a motorcycle and have a habit of not keeping a distance and behave in a hurry have a probability of a traffic accident by $90 \%$.

\section{Discussion}

Precautions are the main factor that ensures the rider is always alert and aware of other road users. If the driver is always alert, he will act right in the face of other riders who can always be reckless. ${ }^{18}$ Driving is not a job that only requires a person to have knowledge and experience about 
Table 2 Risk Factors of Traffic Accidents Occurance on Motorcycle Riders in Semarang City 2017

\begin{tabular}{|c|c|c|c|c|c|}
\hline \multirow[b]{2}{*}{ Variables } & \multicolumn{2}{|c|}{ Groups } & \multirow[b]{2}{*}{ OR } & \multirow[b]{2}{*}{$95 \% \mathrm{CI}$} & \multirow[b]{2}{*}{ p Value } \\
\hline & $\begin{array}{c}\text { Case } \\
(n=50)\end{array}$ & $\begin{array}{l}\text { Control } \\
(n=50)\end{array}$ & & & \\
\hline Speed limit (km/hour) & & & 4.49 & $1.61-12.54$ & 0.006 \\
\hline$\geq 50$ & 19 & 6 & & & \\
\hline$<50$ & 31 & 44 & & & \\
\hline Driver license ownership & & & 3.16 & $1.17-8.51$ & 0.035 \\
\hline Not & 17 & 7 & & & \\
\hline Yes & 33 & 43 & & & \\
\hline Habit of violating the traffic light & & & 1.00 & $0.06-16.44$ & 1.000 \\
\hline Yes & 1 & 1 & & & \\
\hline Not & 49 & 49 & & & \\
\hline Use of lane & & & 4.89 & $2.04-11.72$ & 0.001 \\
\hline $\mathrm{Bad}$ & 29 & 11 & & & \\
\hline Good & 21 & 39 & & & \\
\hline Rider alertness & & & 6.29 & $2.52-15.69$ & 0.000 \\
\hline Late alert & 29 & 9 & & & \\
\hline Alert & 21 & 41 & & & \\
\hline Hasty behavior & & & 3.93 & $1.68-9.15$ & 0.002 \\
\hline Yes & 37 & 21 & & & \\
\hline Not & 13 & 29 & & & \\
\hline Habit of violating the mark & & & 2.57 & $0.89-7.44$ & 0.126 \\
\hline Yes & 13 & 6 & & & \\
\hline Not & 37 & 44 & & & \\
\hline Habit of keeping the distance & & & $7 \cdot 31$ & $3.02-17.70$ & 0.000 \\
\hline Not & 37 & 14 & & & \\
\hline Yes & 13 & 36 & & & \\
\hline Motorcycle type & & & 0.52 & $0.23-1.159$ & 0.160 \\
\hline Automatic & 23 & 31 & & & \\
\hline Manual & 27 & 19 & & & \\
\hline
\end{tabular}

Table 3 Multivariate Analysis Result Risk Factors Traffic Accidents Occurance on Motorcycle Riders Year 2017

\begin{tabular}{lcccc}
\hline Factor & B & p Value & OR & 95\% CI \\
\hline Less alert & 1.448 & 0.005 & 4.255 & $1.540-11.759$ \\
Habit not keeping the distance & 1.650 & 0.001 & 5.209 & $1.997-13.584$ \\
Impulsive behavior & 1.082 & 0.029 & 2.950 & $1.116-7.800$ \\
\hline
\end{tabular}

how it should be driving, but rather the driver's awareness to always be vigilant in the face. ${ }^{19}$ When the driver has a low level of alertness, the driver has difficulty controlling the vehicle, so the risk of traffic accidents will increase. ${ }^{20}$ Check the rearview mirror is an essential thing of being alert, especially to slow the vehicle, stop abruptly, or move lane. ${ }^{16}$ Based on multivariate analysis in this study, indicating that less alert was proven to be a risk factor for motorcycle traffic accidents with values $(\mathrm{p}=0.005, \mathrm{OR}=4.255,95 \%$ $\mathrm{CI}=1.540-11.759)$ means less alert when driving a chance for motorcycle traffic accidents by 4.2 times compared to bikers who are wary.

The result of this research is in line with the research of Arifuddin et al. ${ }^{21}$ found that careless 
riders/less vigilant at risk of traffic accidents increased accidents 3.1 times compared with the alert rider. This study also reinforced the results of Wicaksono et al., ${ }^{22}$ which stated that less-anticipated/less alert driver is the driver's behavior that most often leads to an accident with the percentage of $72.45 \%$. In line with research by Pamungkas, ${ }^{23}$ it contributed to $32.62 \%$ of accidents.

The best protection is the distance between riders and other road users. If a person makes a mistake, a safe distance allows time to react and see opportunities to avoid. Driving at an insecure distance poses the risk of being involved in a crash both from the front of or being hit by a vehicle behind. ${ }^{16}$ Based on Haddon's matrix ${ }^{10}$ driving behavior is a determinant of traffic accidents' pre-event phase. Driving behavior that has the risk of an accident is the habit that does not keep the distance. It is also explained in Sugiyanto and $\mathrm{Santi}^{24}$ determinants of traffic accidents. One of them is the safe distance between vehicles. This study also in line with the theory that the habit of not maintaining the distance proved as a risk factor of motorcycle traffic accidents with the value $(\mathrm{p}=0.001, \mathrm{OR}=5.209,95 \% \mathrm{CI}=1.997-$ 13.584). The habit of not keeping the distance when driving increased a motorcycle traffic accident by 5.2 times.

Research by Riskiansah and Zain ${ }^{17}$ showed that most respondents stated that the accident was the respondent's fault and cause of the rush, that is $52 \%$. Haddon's matrix driving behavior is a determinant in the pre-event phase of traffic accidents. ${ }^{10}$ One of driving behavior is impulsive behavior while driving. Multivariate analysis indicated that impulsive behavior is proven to be a risk factor for motorcycle traffic accidents with values $(\mathrm{p}=0.029, \mathrm{OR}=2.950,95 \% \mathrm{CI}=1.116$ 7.800). When driving, an impulsive behavior increased the chance for a motorcycle traffic accident by 2.9 times compared with riders who do not behave in a hurry.

\section{Conclusion}

Variables proven to be a risk factor for traffic accidents on motorcyclists are less alert, habits of not keeping distance, and impulsive behavior.

\section{Conflict of Interest}

The authors state that there is no conflict of interest.

\section{Acknowledgments}

Acknowledgments to Traffic Unit of Police Resort of Semarang city, Academic Section of Master in Epidemiology Study Program at Universitas Diponegoro, and all parties who have helped this study.

\section{References}

1. Karim NM, Saad R, Santikarn C, Peden M, Toroyan T, Iaych K, et al. Road safety status in the WHO South-East Asia Region, 2013 [Internet]. New Delhi, India: WHO Regional Office for South-East Asia; 2013 [cited 2017 December 22]. Available from: https://apps. who.int/iris/handle/10665/205873.

2. Badan Pusat Statistik. Jumlah penduduk menurut provinsi [Internet]. Jakarta: Badan Pusat Statistik; 2010 [cited 2017 December 22]. Available from: https://www.bps.go.id/ linkTabelStatis/view/id/1267.

3. Badan Pusat Statistik. Jumlah kecelakaan, korban mati, luka berat, luka ringan, dan kerugian materi yang diderita tahun 19922012 [Internet]. Jakarta: Badan Pusat Statistik; 2012 [cited 2017 December 22]. Available from: https://www.bps.go.id/ index.php/linkTabelStatis/1415.

4. Badan Pusat Statistik Jawa Tengah. Banyaknya kecelakaan lalu lintas, korban, dan nilai kerugiannya di wilayah Polda Jawa Tengah [Internet]. Semarang: Badan Pusat Statistik Jawa Tengah; 2013 [cited 2017 December 22]. Availablefrom: https://jateng. bps.go.id/index.php/linkTabelStatis/899.

5. Badan Pusat Statistik Jawa Tengah. Data kependudukan tahun 1993-2016 [Internet]. Semarang: Badan Pusat Statistik Jawa Tengah; 2017 [cited 2017 December 22]. Available from: https://www.jateng.bps. go.id.

6. Satuan Polisi Lalu Lintas Kepolisian Resor Kota Besar Semarang. Data kecelakaan lalu lintas 2014-2016. Semarang: Kepolisian Resor Kota Besar Semarang; 2016.

7. Satuan Polisi Lalu Lintas Kepolisian Daerah Jawa Tengah. Data kendaraan bermotor tahun 2014, 2015, dan 2016. Semarang: Kepolisian Daerah Jawa Tengah; 2017.

8. Sahabudin, Wartatmo H, Kuschitawati S. Pengendara sebagai faktor risiko terjadinya kecelakaan lalu lintas sepeda motor tahun 2010. BKM. 2011;27(2):94-100.

9. Marsaid, Hidayat M, Ahsan. Lalu lintas pada 
pengendara sepeda motor di wilayah Polres Kabupaten Malang. JIK. 2013;1(2):98-112.

10. Lin MR, Kraus JF. A review of risk factors and patterns of motorcycle injuries. Accid Anal Prev. 2009;41(4):710-22.

11. Rosyida SNL, Daryono. Kajian kecelakaan lalu lintas di jalan arteri pada jalur pantura wilayah Tuban. Swara Bhumi. 2015;1(1):8896.

12. Marwan AA, Wicaksono A, Abusini S. Dampak pemberlakuan kebijakan sepeda motor menyalakan lampu utama terhadap pengurangan kecelakaan di Kota Surabaya. Rekayasa Sipil. 2015;9(2):88-96.

13. Hidayati A, Hendrati LY. Analisis risiko kecelakaan lalu lintas berdasar pengetahuan, penggunaan jalur, dan kecepatan berkendara. JBE. 2015;4(2):275-87.

14. Azizirrahman M, Normelani E, Arisanty D. Faktor penyebab terjadinya kecelakaan lalu lintas pada daerah rawan kecelakaan di Kecamatan Banjarmasin Tengah Kota Banjarmasin. JPG. 2015;2(3):20-37.

15. Eustace D, Indupuru VK. A simplified method for analyzing factors contributing to motorcyclists' fatal injuries in Ohio. Adv Transp Stud. 2011;24:85-96.

16. Direktorat Jenderal Perhubungan Darat Departemen Perhubungan Republik Indonesia. Buku petunjuk tata cara bersepeda motor di Indonesia [Internet]. Jakarta: Direktorat Jenderal Perhubungan Darat Departemen Perhubungan Republik Indonesia; 2009 [cited 2017 December 22]. Available from: https://dishub. malangkota.go.id/wp-content/uploads / sites/16/2016/05/BUKU-PETUNJUKTATA-CARA-BERSEPEDA-MOTOR-DIINDONESIA.pdf.

17. Riskiansah A, Zain I. Analisis pola tingkah laku pengendara sepeda motor di Kota Surabaya dengan Driver Behavior
Questionnaire (DBQ) [Internet]. Surabaya: Institut Teknologi Sepuluh November; 2003 [cited 2017 December 22]. Available from: http://digilib.its.ac.id/public/ITS-paper19525-1307100086-Paper.pdf.

18. Supriyono S. Implementasi traffic accident analysis guna menanggulangi kecelakaan lalu lintas [thesis]. Semarang: Universitas Diponegoro; 2010 [cited 2017 December 22]. Available from: http://eprints.undip. ac.id/24018/1/SABAR_SUPRIYONO.pdf.

19. Firmansya A, Rahim MR, Wahyu A. Faktor yang berhubungan dengan perilaku safety driving pada pengemudi mobil pengangkut semen curah di PT. Prima Karya Manunggal (PKM) Kab. Pangkep tahun 2013 [undergraduate thesis]. Makassar: Universitas Hasanuddin; 2013 [cited 2017 December 22]. Available from: http://repository.unhas.ac.id/bitstream/ handle/123456789/5919/JURNAL. pdf?sequence $=1$.

20. Sutalaksana IZ, Mahachandra M. Aktivitas sekunder audio untuk menjaga kewaspadaan pengemudi mobil Indonesia. J@TI Undip. 2012;7(3):185-90.

21. Arifuddin A, Napirah MR, Asfin HSN. Risk factors in road traffic accidents in the city of Palu, Indonesia. PHI. 2017;3(1):23-9.

22. Wicaksono D, Fathurochman RA, Riyanto B, Wicaksono YI. Analisis kecelakaan lalu lintas (studi kasus - Jalan Raya Ungaran - Bawen). JKTS. 2014;3(2):345-55.

23. Pamungkas NS. Mengenal perilaku pengendara kendaraan dalam upaya mencegah terjadinya kecelakaan di jalan raya. TEKNIS. 2014;9(1):13-8.

24. Sugiyanto G, Santi MY. Karakteristik kecelakaan lalu lintas dan pendidikan keselamatan berlalulintas sejak usia dini: studi kasus di Kabupaten Purbalingga. Semesta Teknika. 2015;18(1):65-75. 